\title{
VIDA Y VERSOS DE LUIS QUINTONES DE BENAVENTE
}

Abraham Madroñal Durán.

\section{Biograffa.}

Poco se sabía hasta ahora del más grande entremesista de su tiempo y padre del género, el toledano Luis Quiñones de Benavente o Luis de Benavente, como se le conocía casi generalmente en su época. Los datos seguros se resumian en muy pocas palabras: nació en Toledo, fue licenciado y murió en 1651 , y ni siquiera todas esas afirmaciones se podian sostener en documentos localizados sobre tan curioso personaje.

Como siempre que faltan los datos sobre un autor célebre surgen las hipótesis que intentan sustituirlos, y así se han aventurado las más curiosas teorias sobre su origen familiar, estudios, profesión, etcétera. Hoy, afortunadamente, disponemos de algún dato documental más que nos permita perfilar la biografia de este hombre singular que fue el toledano Luis de Benavente ${ }^{1}$.

Se ha supuesto su nacimiento entre 1589 y $1595^{2}$, basándose para ello los investigadores en varios datos poco seguros, a saber: que en la justa de 1609 ó 10 era un adolescente ${ }^{3}$, y que en la alusión de Tirso (hacia 1625) era

1 Así era conocido en su época, excepcionalmente se le denomina Luis de Benavente y Quiñones y solo en la portada de su obra, la Jocoseria, le denomina su amigo Manuel Antonio de Vargas Luis Quiñones de Benavente, que es, curiosamente, como ha pasado a la posteridad.

2 Hannah E. Bergman aporta las fechas 1590-1593. Da preferencia a la segunda en su ed. de los Entremeses, Salamanca, Anaya, 1968. E. Cotarelo en su magna Colección de entremeses, loas, bailes, jácaras y mojigangas desde fines del siglo XVI a mediados del XVIII, I, Madrid, Nueva Biblioteca de Autores Españoles, 1911, pág. LxxIV, apuntaba como fecha de nacimiento "antes de expirar el siglo XVI".

3 Es la opinión del ilustre estudioso del género Eugenio Asensio en su Itinerario del entremés. Desde Lope de Rueda a Quiñones de Benavente, Madrid, Gredos, 1971, página 126, donde escribe a propósito del único soneto conocido de nuestro autor: "Este soneto, frío y académico, me huele a rito de pubertad de un muchacho precoz." En efecto, la poesía tiene mucho de ritual. 
todavia "mozo" ". Ninguna de las dos afirmaciones es segura; la primera se basa en la alusión del vejamen, según la cual Baltasar Elisio de Medinilla pregunta —refiriéndose a Benavente- "si ha sido suyo el soneto" ${ }^{5}$, y más que referirse a la edad del participante, quiere aludir a que no tenia el escribir poesía "seria" como cosa habitual y era una referencia normal en este tipo de escritos satíricos ${ }^{6}$. La segunda de las referencias a un entremesista, "mozo, cuerdo, cortesano, / que no ha dicho mal de poeta 7", que damos por sentado se refiere a nuestro autor, como asi lo han reconocido prestigiosos investigadores antes, tampoco supone referencia alguna a su edad, porque "mozo" significa también "soltero", adjetivo que se aplica a la perfección a un clérigo, como lo era nuestro entremesista, según tendremos oportunidad de demostrar ${ }^{8}$.

Sin embargo no se ha prestado atención al testimonio de un contemporáneo del autor, el singular don Diego Duque de Estrada, que afirma en su curiosa autobiografía, Comentarios del desengañado de sí mismo (c1614-46) que Benavente habría asistido a la famosa Academia de Fuensalida toledana ${ }^{9}$, junto con otros poetas como Barrionuevo (gracioso entremesista, que le pudo influir a nuestro autor ${ }^{10}$ ), Matías Montero (también autor dramático), Vaca de Herrera, Medina Abasco y él mismo. El que Duque de Estrada situara aquella Academia en 1602 ó 1603 se ha tomado como cosa imposible, pues según los cálculos cronológicos de los eruditos Benavente tendría poco más de trece años. Sin embargo, pretendemos demostrar en otro lugar que Duque de Estrada no miente cuando se refiere a personajes contemporáneos de su Toledo natal (salvo en el poco probable caso de su tutor y del rocambolesco asesinato de su novia, juicio y posterior fuga), y todos los nombrados por él son rigurosamente históricos en el momento que recrea, pero puede que su memoria le falle y por eso cambie nombres y fechas. La mayoría de

4 Bergman, Luis Quiñones de Benavente, Madrid, Castalia, 1965, pág. 54.

5 El vejamen, y los poemas, están incluidos al final del libro de Mateo Fernández Navarro Floresta espiritval ..., Toledo, 1613, fol. 216.

- El mismo Juan Ruiz de Santa María, en el vejamen que él mismo dio al certamen celebrado en Toledo en 1614, que comienza "Otra vez buelbo a templaros", BNM, ms. 4.100, fol. [4], escribe de don Francisco Vaca: "afirma y jura / que a sido suyo el soneto", y sin embargo "nunca le tube en mi vida / por poeta".

7 En la comedia de Tirso Tanto es lo demás como lo de menos, citada por Bergman, Luis Quiñones..., págs. 51-52, quien resume las opiniones de Blanca de los Ríos, Cotarelo y Kennedy.

- Véase, por ejemplo, el Tesoro de la lengua castellana o española de Covarrubias, Barcelona, 1987, pág. $808 \mathrm{~b}$ : "Moço se toma algunas vezes por el que aún no se ha casado".

- Comentarios del desengañado de si mismo, ed., introd. y notas de H. Ettinghausen, Madrid, Clásicos Castalia, 1982, pág. 94.

10 Véase acerca de este personaje nuestro estudio en curso de publicación, "Gaspar de Barrionuevo, un poeta toledano amigo de Lope de Vega", en Voz y Letra, IV, 2. 1994. 
los personajes por él aludidos participa en la justa toledana de 1605 y en preliminares de libros que se imprimen por esos años, tal es el caso del San José de Valdivielso ".

Tampoco se prestó la debida atención a otro testimonio de un contemporáneo más, Sebastián Francisco de Medrano, el cual relaciona a Benavente junto con otros escritores anteriores a él y a los de su generación, entre los que cuenta al discreto de Palacio, don Antonio Hurtado de Mendoza ${ }^{12}$.

Así las cosas, también nos proponemos deshacer algunas hipótesis sobre la familia de nuestro autor. Se le habia supuesto relación familiar con los Condes de Benavente, emparentado con el cómico Luis de Quiñones (y se había llegado a decir que tal vez fuesen la misma persona ${ }^{13}$ ), pero la realidad es que Luis de Benavente fue familia de los Benavente y Quiñones toledanos, hijo de Cristóbal de Benavente y sobrino de Pedro de Benavente y del licenciado Francisco de Benavente, los cuales pertenecían a un nivel medio en la sociedad toledana, pues eran funcionarios del Santo Oficio, rectores y capellanes de hospital, mercaderes o representantes de la política municipal; también era pariente de Ana de San Juan, vecina de Madrid y casada con el mercader Juan de Santillana.

$\mathrm{He}$ aqui su partida de bautismo, que hemos localizado en la toledana capilla de San Pedro. Dice el Libro para escrevir los baptismos [...] de Sant Pedro de la Santa Iglesia de Toledo, desde el principio del año de $1569^{14}$ :

En tres días del mes de septiembre de mill y qui[nient]os y ochenta y uno, yo el bac[hill]er Fr[ancisc]co de Torres, tenyente cura de la capilla de Sant P[edr]o, baptizé a Luys, hijo de Xpual de Venauente y de Luisa Ana, su mujer. Fueron sus compadres el doctor Andrada y Ursula de Venavente. Advirtióse a los compadres la cognación spiritual, siendo a todo t[estig]o P [edr]o de Venauente y Fran[cis]co Hernández.

El B[achi]ller Francisco de Torres.

Asi pues, fue en 1581 y no hacia $1590,93,95$ o finales de siglo, como se había dicho en diferentes ocasiones, cuando nació nuestro entremesista, el cual se confirma en la misma capilla antes de 1590 . Su pariente Pedro de Be-

11 Véase el libro de C. Pérez Pastor, La imprenta en Toledo, Madrid, 1886, páginas $184 \mathrm{~b}$ y $185 \mathrm{a}$.

12 Véase su obra Favores de las musas, que publica A. Castillo Solórzano en Milán, 1631, especialmente la "Epistola al que leyere", en que refiere el último que era príncipe de la más célebre Academia de Madrid, y la carta que le dirige el propio Medrano a Castillo Solórzano, donde cita —entre los de más edad que él mismo- a "vn licenciado Luys de Benauente".

13 Para todas estas posibles identificaciones véase el libro citado de H. E. Bergman, págs. 42-44.

14 Fol. 102v. ${ }^{\circ}$ Archivo de la Capilla de San Pedro, Catedral. Desde aquí hemos de dar las gracias al sacristán de la misma, don Eduardo Alvarez. 
navente, tío según nuestras conjeturas, es el todopoderoso de la familia, hombre bien relacionado, miembro del Santo Oficio de Toledo, parece ser el que supervisa y dirige a los miembros de su familia $y$ lo veremos aparecer varias veces a lo largo de la vida de nuestro entremesista ${ }^{15}$.

Igualmente, mucho se habia escrito sobre su posible formación universitaria. Para Rosell era licenciado en jurisprudencia ${ }^{16}$, Cotarelo pensaba simplemente que tal título obedecía a que al final de su vida se había hecho clérigo (seguramente, supondría el investigador, tal fecha correspondería a la época en que dejó de escribir para el teatro por razones morales) ${ }^{17}$. Tales hechos vienen hoy a negarse, como tendremos ocasión de demostrar. En primer lugar, Benavente es posible, aunque no hay pruebas documentales, que estudiara en la Universidad de Santa Catalina de su ciudad natal, aunque no sabemos si amplió estudios en otras universidades, según aporta un estudioso toledano de estos temas, que lo cita entre los alumnos famosos de la citada universidad, junto con fray Luis, Zorrilla y otros, aunque sin justificarlo ${ }^{18}$.

Además, Benavente no se ordenó al final de su vida, sino que fue clérigo presbitero desde muy joven y parece que tal fue su profesión, pues bien sabido es que del teatro no se podía sustentar, aunque de vez en cuando sus méritos dramáticos le granjearan alguna recompensa, tal y como sabemos que ocurrió por documentos ya publicados en 1631 y 1637 y como encontramos en su testamento, documento hasta hace poco perdido e inédito. El dato precioso lo hemos encontrado en un protocolo toledano, precisamente en el de un escribano que tuvo mucho que ver con nuestro autor, Juan Ruiz de Santa María, poeta de mérito, encargado del vejamen de la justa de 1614 en Toledo y el que obtiene el primer premio de sonetos en el certamen de $1609 \mathrm{y}$ quiere delegar en nuestro Benavente. El 27 de septiembre de 1612 acude ante el escribano poeta Juan Carrasco, patrón de la capellanía que instituyera Ana de San Juan, su sobrina, el cual ante el fallecimiento del licenciado Francisco Carrasco, capellán que se ocupaba de las misas por la fundadora, declara

que de todos los llamados por la d[ic]ha fundaçión de capellanía no ay ninguno que sea saçerdote, nombraba e nombro por tal capellán al liçenciado

15 De la familia de los Benavente sabemos que tuvo mucho que ver en la Cofradia de la Santa Caridad de Toledo, pues en 29 de marzo de 1586 ingresa como cofrade el licenciado Francisco; en 4 de septiembre de 1589, Melchor de Benavente, jurado hijo de Pedro; el 28 de octubre de 1594, el propio Pedro, y el 23 de julio de 1606, Eugenio de Benavente, también hijo de Pedro. Nuestro poeta, sin embargo, no perteneció a esta institución. (Véase Libro de entrada de cofrades de la Cofradía de la Santa Caridad de Toledo, Archivo de la Diputación, Toledo.)

16 En su estudio introductorio a la Colección de piezas dramáticas, entremeses, loas y jácaras, I, Madrid, Libros de Antaño, 1872.

17 Op. cit., introd., pág. lxxv.

18 Florentino Gómez, Biografía de la Universidad de Toledo, Toledo, IPIET, 1980, pág. 52 . 
Luis de Venauente y Quiñones, clérigo presvitero, v[ecin]o desta d[ic]ha çiudad de Toledo, que está presente, que es el pariente más cercano que ay de la $d[i c]$ ha fundadora que sea saçerdote, para que el susod[ic]ho tenga la $\mathrm{d}$ [ic]ha capellanía y diga en cada un año por el ánima de la fundadora cinqüenta y dos misas ${ }^{19}$.

La fecha de su ordenación de menores nos es conocida. En el manuscrito 3.825 de la Biblioteca Nacional de Madrid se conserva un documento titulado "Memoria de las personas que en la c[iuda]d de Toledo ordenó el $\mathrm{s}$ [eño]r obispo de Salona a siete dias del mes de marzo de 1598" y entre ellas figura:

Luis de Benauente, [hijo] de Christóbal de Benauente y Luisa Ana, de $\mathrm{T}$ [oled] $\mathrm{o}^{20}$.

No hemos encontrado en el Archivo Diocesano de Toledo el correspondiente expediente que confirme tal noticia, pero si nos consta que nuestro autor había recibido órdenes menores por esos años.

En 1609 lo encontramos como paje del Arcediano de Toledo. Por lo menos, el capellán mozárabe, y también escritor, Eugenio Robles encarga a D. Juan Vázquez, cura de Santa Justa, que le cobre lo que le adeudan varias personas, y entre ellas:

Anse de cobrar beinte $r$ [eale]s de Luis de Benabente, paje del $s$ [eñor] arced [ian]o de $T$ [oled] ${ }^{21}$.

Y es muy probable que este Benavente sea nuestro Luis Quiñones de Benavente por la relación que vamos a seguir encontrando entre el arcediano de Toledo, don Francisco de Móxica o de Mújica y nuestro autor, como veremos. El caso es que en 1610 Pedro de Benavente, como albacea con Juan Bautista de Madrid y patrón de una capellanía instituida por Alejo Pérez por su testamento en 1580 en la toledana parroquia de San Juan Bautista y ante la muerte del licenciado Francisco de Benavente, presumiblemente hermano suyo, el cual era rector del Hospital del Rey y capellán de la citada capellanía, declara que:

nombro por tal capellán de la d[ic]ha capellanía a Luis de Venavente, clérigo de menores hórdenes, $\mathrm{v}$ [ecin]o desta ciudad, que es persona ábil y suficiente

\footnotetext{
19 AHPT, Prot. de Juan Ruiz de Santa Maria, año 1612 , n. ${ }^{\circ} 2.868$, fols. dmc. ${ }^{\circ}$ a dmcvij.

20 Ya publicado antes en nuestro trabajo: "Un romance de Quevedo atribuido a Quiñones de Benavente...", en Manuscrt. KAO, V, 1993, págs. 15 a 24.

21 Archivo Parroquial de San Nicolás de Toledo, papeles sueltos. Publicado por M. Arellano García, La capilla mozárabe o del Corpus Christi, Toledo, 1980, páginas 207-208.
} 
para hello, en quien concurren las calidades de $d$ [erech]o necesarias pa[ra] que a título de la $\mathrm{d}$ [ic] ha cap[ellaní]a se pueda hordenar y ordene como pretende ${ }^{22}$.

Se exigía que el elegido fuese clérigo, y el nombrado, Luis de Benavente, se obligaba a velar por el alma de Alejo Pérez y a dedicarle dos misas semanales. El caso es que, en efecto, en 1611, "Luis de Benabente, clérigo de grados d T[oled]o", decide ordenarse de epístola y presenta por testigo al licenciado Juan de Cerezo (de 33 años, poco más o menos), presbitero, capellán del arcediano de Toledo don Francisco de Mújica; también presenta al licenciado Francisco de Santa María (de 40 años más o menos), cura de la mozárabe de San Marcos, los cuales afirman que Luis posee la capellanía de Alejo Pérez y la que fundó Úrsula de Benavente, casada con Alonso Díaz Francés. Dicen que es parroquiano de San Vicente, donde "ay falta de clérigos", lo cual ratifica el licenciado Merchante, cura de la citada parroquia. A este párroco se le notifica que publique cómo Benavente se queria ordenar, cosa que hace un domingo, y a la semana siguiente Cristóbal Gómez Castellanos, teniente de cura, informa de la publicación por si alguien tenía algo en contra de la nueva ordenación y además apunta :

que el $\mathrm{d}[\mathrm{ic}]$ ho Luis de Venavente es de buena vida y costumbres, y mereçe ser promobido a las órdenes que pretende ${ }^{23}$.

Así pues, se ordena de epistola y evangelio, y en 1612 decide ordenarse de misa, cosa que hace a primeros de septiembre de ese año. Pasadas las correspondientes publicaciones, vuelve el licenciado Cristóbal Gómez Castellanos a informar el 5 de ese mes que "Luis de Benauente es birtuoso, de buena bida y fama, y a exercitado [...] de diácono y subdiácono más de seis vezes" ${ }^{24}$. El caso es que muy poco después, el 27 de septiembre de ese año, ya como licenciado, se le nombra capellán de la capellanía fundada por Ana de San Juan, por ser su pariente más próximo que tuviera el grado de clérigo que ella pretendia. Ahora se hace llamar Luis de Benavente y Quiñones y antecede su título de licenciado, nunca usado anteriormente, porque la dicha fundadora había instituido que su capellán primero fuese su hermano Francisco de Madrid Carrasco y después de sus días el primer hijo de su otro hermano Baltasar de Valladolid, "que primero cante misa y fuere clérigo presbitero $[\ldots]$ y en su falta, al pariente mío que más propinco fuese clérigo". Se

\footnotetext{
22 Archivo Diocesano de Toledo (ADT), Capellanías, 1610, leg. 599, fol. 1.

23 ADT, Ordenes de 1611, leg. 169. El documento consta de 4 folios, la cita es del

24 Ibíd., 1612, el documento consta de 3 folios, la cita del 1.
} último. 
exigía ser "de buena vida, fama y exemplo" además, pero no sabemos si la frase era una mera fórmula ${ }^{25}$.

El caso es que el 1 de agosto de 1616 comparece Juan Carrasco, patrón perpetuo de la capellanía, y dice:

Pedro de Benavente, familiar del Santo Oficio de la Inquisición de esta c[iud]ad de Toledo, $\mathbf{v}[$ ecin]o della, en nombre de doña Inés de Quiñones, viuda que fue de Baltasar Arnalte, dif[unt]o, v[ecin]o de la villa de Villafranca de Gaytán, e por virtud del poder que della tuvo, vendió e impuso a censo en favor de las d[ich]as memorias [de Ana de San Juan] e del d[ich]o Juan Carrasco y del licenciado Luis de Benavente e Quiñones, clérigo presuítero, $\mathbf{v}[$ ecin]o desta $\mathrm{d}[\mathrm{ic}]$ ha ciudad, patrón e capellán dellas, en su nombre [dio?] mil cuatrocientos maravedís de censo e tributo en cada un año ${ }^{26}$.

En ese mismo documento Andrés de Villalba, heredero de Polán, también presbítero, impone un tributo por el cual ha de pagar "al licenciado Luis de Benavente e Quiñones, clérigo previtero, capellán que al presente es de la dic[ha] capellanía, que está presente".

Poco parece que le duró esta situación de cierta tranquilidad y bonanza económica. No sabemos por qué, pero un año después comparece nuestro autor ante su amigo Juan Ruiz de Santa María y dice:

Sepan quantos esta carta de poder vieren, como yo, Luis de Venabente e Quiñones, clérigo presvít[er]o, v[ecin]o desta ciudad de $\mathrm{T}$ [oled]o, otorgo e co$\mathrm{n}[\mathrm{ozc}] \mathrm{o}$ que doy mi poder cumplido en bastante forma a Marcos de San $\mathrm{P}[$ edr]o Ordóñez, v[ecin]o desta ciudad de T[oled]o, espeçialmente para que en my nombre e para él mismo en su causa propia reçiua y cobre de Jorje de Torres Berrio, $\mathbf{v}[$ ecin]o desta çiud[a]d de $\mathrm{T}[$ oled]o, tes[orer]o por su Mag[esta]d de sus alcabalas e rrentas rreales desta ciudad de T[oled]o e su partido, es asauer noventa e ocho rreales que yo e de aber en el terçio de fin de $\operatorname{diz}[i e m b r]$ e deste presente año de mil seiscien[to]s e diez y siete, como capellán que soy de la capellanía de Alejo Pérez sobre juros del s[eño]r don Pedro López de Ayala, conde de Fuensalida, para cuya cobr[anz]a le pongo e subrrogo e transfiero en el d[ich]o Marcos de San P[edr]o Ordóñez mis derechos y actiones rreales y personales [...]. En la dicha ciudad de Toledo, en veynte e ocho dias del mes de nobienbre de mil e seiscie[nt]os e diez y siete $\mathrm{a}[\tilde{n}] \mathrm{o}[\mathrm{s}]$, siendo testigos Benito de Luna e Cristóbal de T[oled]o e Grabiel F[ernánd]ez, y lo firmó de su nombre. Luis de Benavente y Quiñones ${ }^{27}$.

Un poco antes había otorgado un poder en los siguientes términos:

25 ADT, Capellanías (de Ana de San Juan), 1589. Leg. 19, exped. 220.

28 AHPT, Prot. de J. Ruiz de Santa María, 1616, n. ${ }^{\circ} 2.872$, fol. 1004.

27 Ibíd, n. ${ }^{\circ} 2.874$, fol. iumceeev v. ${ }^{\circ}$ 
Sepan quantos esta escritura de poder bieren como yo, el licenciado Luis de Benabente y Quiñones, clérigo presbitero, vecino desta ciudad de Toledo, otorgo y conozco que doy e otorgo mi poder cumplido y bastante, qual de Dios se requiere para baler a el licenciado Alonso Martín, clérigo prebítero, v[ecin]o desta ciudad de T[ole]do, para que por mi y en mi nonbre y para mí reciba y cobre todos y qualesquier maravedis $\mathbf{y}$ otras cosas que me son $\mathbf{y}$ fueren debidas y se me debieren por qualesquier personas de qualesquier partes, ansí de los frutos de mis capellanías como de qualquier forma que sea por escrituras públicas o sin ellas y en otra qualquier forma y manera que sea, de plaço pasado e porbenir $y$ de lo que reçibiere y cobrare otorgue cartas de pago y finiquito ${ }^{28}$.

Nunca parece que tuviera una posición social brillante, como el caso de tantos escritores famosos, y parece cierta aquella afirmación de un personaje de sus entremeses que dice que el autor "anda mendigando gracias". Su vida es pobre, y, casi al final, cuando abandona el teatro, casi podríamos decir que miserable. Tal es la impresión que sacamos de su testamento. En él solo se acuerda en sus últimos momentos de la mujer que le había atendido en sus largas enfermedades, quizá una de las causas para abandonar la escena, como sugiere su amigo y editor Manuel Antonio de Vargas ${ }^{2}$.

Benavente llega a Madrid ese año 1617, e inmediatamente ingresa en la Academia de Medrano, ya referida (cfr. supra). Todas las referencias que tenemos a su persona hasta ese momento le relacionan con los bailes, nunca con los entremeses ${ }^{30}$, género que - según nuestra opinión- empezaría a cultivar justo desde ese momento y ya viviendo en Madrid. Hasta entonces Benavente es conocido como músico de guitarra, lo cita Suárez de Figueroa en su Plaza universal de 1615 (pero aprobaciones de 1612) y también otros textos poco citados hasta el momento, como la Sátira segunda contra Rámila, de Lope, fechada entre 1617-18:
Ahora entre tus hurtos y centones
estés, ; oh desdichado Torrecillas
sastre! o lopuizando conclusiones
o ensuciando de Henares las orillas;
dejando de remiendos más retales
que ha hecho Benavente seguidillas ${ }^{31}$.

28 Ibid., n. ${ }^{\circ} 2.874$, s./f.

20 Citamos por la ed. de Rosell, I, pág. xviii. Llama la atención el olvido de Toledo, que apenas aparece en su producción dramática. Parece notarse cierto resentimiento del hijo no muy bien tratado en su tierra natal. En la Jácara de doña Isabel, la ladrona, se puede leer: "Fue a probar adonde llega / la agudeza toledana; / y sirviendo a un mercader / de hacienda aterciopelada / le pellizcó los talegos." (Cotarelo, Colección, página $575 \mathrm{a}$.)

30 Véase la op. cit. de Bergman, págs. 49-50, donde reproduce textos de Tirso y Antonio Hurtado de Mendoza.

${ }^{31}$ Apud J. Entrambasaguas, Estudios sobre Lope de Vega, II, Madrid, CSIC, 1947, pág. 337. Le extraña al editor lo de las seguidillas, pero la profesora Bergman demuestra que es una de las estrofas preferidas de nuestro autor. 
Este Benavente músico, amigo de bailes, aparece con cierta frecuencia en los textos de la época formando pareja con otro músico singular, como fue Palomares, también muy recordado por Lope. Dice asi una conocida glosa del cantar "Aunque más, marido mío":

\author{
Dame en tonillos a pares \\ mil chanzonetas de amores, \\ que no las pondrán mejores \\ Benavente o Palomares \\ con mil dares y tomares \\ que tienen uno por uno ${ }^{32}$.
}

Benavente parece que componia los tonos de los bailes que acompañaban los entremeses, pero poco después decidió intentar componerlos él mismo, actividad que debió de empezar en la década de 1620. Benavente se hace cortesano, incluso llega a gustar al mismo Rey, y en la década de los 30 , coincidiendo con la inauguración del Buen Retiro, compone sus entremeses y bailes para representar en el Real Sitio. Hemos documentado que se le pagan 400 reales por dos bailes en 1636, 1.200 por seis en 1637, 250 por uno y un entremés un año después, 400 en 1638 (por dos veces) ${ }^{33}$.

Muy poco después de la citada fecha, si no el mismo año, Benavente tiene que retirarse del teatro, debido a sus enfermedades, como recordaba su amigo Vargas y viene a confirmar el siguiente documento, otro gasto ordenado por Su Majestad en San Juan y Santa Isabel de 1638, según el cual se deben dar:

Mill r[eale]s a Luys de Benauente por limosna p[ar]a curarse ${ }^{\mathbf{3 4}}$.

Poco menos que mendigando debió de sobrevivir el gran entremesista y gracias a la generosidad de Felipe IV, que es de suponer estuviera agradecido a sus burlas-veras, pues le sigue otorgando estas limosnas hasta su muerte. Como también se las otorgaba al gran Juan Rana, sin duda porque ambos le hicieron pasar muy buenos ratos a él y a sus allegados.

El autor debió de tener su momento de esplendor en esos años, en los que participa en reuniones literarias, como las justas de 1637 y 1638 , para las que colabora con poemas jocosos, muy del estilo de las chanzas de sus entreme-

33 BNM, ms. 17.557, fol. 53. Editado en Poesía erótica del Siglo de Oro, Barcelona, Crítica, 1984, pág. 169, aunque los editores manifiestan desconocer quién es este Benavente.

ss BNM, ms. 7.797, "Relaçión y qüenta de gastos hechos en el Sitio Real de Buen Retiro en los años 1636 y 1637 por orden de Su Mag[est]ad, pagados del din[er]o de gastos secretos", y años sucesivos hasta 1639 , fols. $136 \mathrm{v}^{\circ}, 137,139 \mathrm{v}^{\circ}$ y 161.

34 Doc. cit, en nota anterior, fol. 160. 
ses ${ }^{35}$. También era asiduo asistente de las Academias celebradas en aquel momento, como las del Buen Retiro de 1637, y otras, según recuerda Lanini y Sagredo en su Ramillete de sainetes escogidos (1672), al emparejarlo con un poeta academicista por excelencia, Pantaleón de Ribera:

\author{
Pantaleón su pie glosa \\ con Benavente \\ $y$ asi cifran en poco \\ mucho juguete ${ }^{*}$.
}

Da la impresión de que el clérigo Benavente se dejaba ganar por la frivolidad, pero no hay que olvidar que Luis de Benavente era tenido entre sus contemporáneos por hombre cuerdo, que no se metía jamás con sus compañeros de profesión y que no rebasaba nunca los límites de la decencia ni de la moral en sus obras. Queda muy claro en una cita preciosa y muy poco conocida de otro escritor amigo, como fue Salas Barbadillo, el cual escribe en sus Coronas del Parnaso y platos de las musas:

Empeçó la novia Tropeçona y Soruedora a entonar vna inmensa copia de seguidillas picantes, agudas y de buen aire: estas olian al Licenciado Benauente, porq[ue] tiniendo muy buen chiste, sal y garauato, no se profanauan con indecencias, no eran desacatadas ni desatacadas ${ }^{37}$.

A pesar de todo, Benavente tuvo que sufrir la maledicencia de algún contemporáneo envidioso, que en otro lugar hemos sugerido pudo ser Quevedo ${ }^{38}$. La Jocoseria sería un intento de sus amigos de salir al paso de calumnias y chismorreos en un momento en que Benavente ya no se acordaba casi de su labor como entremesista. Curiosamente, los amigos que le dedican versos en los preliminares son hoy escritores poco conocidos (excepto Vélez, claro), relacionados con nuestro autor a través de la Congregación del Santísimo Sacramento.

Uno de estos amigos fue su pariente don Diego de Contreras, especie de protector del entremesista, que también colabora en los preliminares de su

35 Los reproducimos en nuestro apéndice. Véase el artículo de H. E. Bergman sobre el certamen de 1638, "El Juicio final ...", en $B R A E$, LXXV, 1975, págs. 551-610.

* En la obra de K. Brown, Anastasio Pantaleón de Ribera (1600-1629), Maryland, 1980 , pág. 87 .

37 Madrid, 1635, pág. 126. Ya el Conde de Schack en su Historia de la literatura y el arte dramático en España, V, Madrid, 1887, pág. 231, había advertido que nuestro autor escribió entremeses para el teatro del Buen Retiro “y quizás esta circunstancia explique satisfactoriamente que se note en ellos menos licencia y libertad que en la mayor parte de las demás composiciones de esta clase. Siendo la dicción de los suyos muy urbana y culta".

38 Véase nuestro trabajo citado "Un romance de Quevedo atribuido a Quiñones de Benavente ...". 
Jocoseria, aunque sin declarar su nombre, con las décimas que empiezan " $\mathrm{Be}$ navente, ya que hallaste" ${ }^{39}$. Debió de formar parte con nuestro autor y con otros poetas del momento como Bocángel de academias ocasionales como la celebrada en casa del contador Agustín de Galarza, por lo menos en los años 1640 y 1641 . Benavente le pide dinero prestado varias veces, como aclara el siguiente billete, que acompaña a unos versos suyos que luego reproducimos:

El villete

S[eño]r, bien beo mi grandísimo atrebim[ien]to, pero yo no tengo otra persona a quien bolber los ojos. Mi neçesidad aun es mucho más de lo que significo y mi aflicçión es mayor, si no tubiera a V[uestra] M[erce]d por mi amparo. Suplícole lo haga y me saque de tanto aprieto, que toda mi bida seré esclabo de V[uestra] M[erce]d, siendo pregonero de su mucha caridad, a quien Dios dé lo que mereze y yo deseo. De casa oy biernes a 14 de di[ziemb] re de 1640 .

De V[uestra] M[erce]d el menor criado

$$
\text { Luis de Benabente y Quiñones [rúbrica] }{ }^{40} \text {. }
$$

Benavente debia de ser capellán de don Diego, parece que se ocupaba de algunas de las capellanías de este, como aclara el siguiente billete, con que le responde Contreras:

Señor mío, no lleban los doçientos porque es mal número p[ar]a ser pregonero mío, y asi lleban çiento y quarenta y siete, que a ninguno en el mundo se an dado si no es a V[uestra] M[erce]d, que tan más merezidos los tiene cada año, y porque lo monta la capellanía del que se sigue de quarenta y uno. Muchos biba V[uestra] M[erce]d, que yo se los adelantaré siempre, rogando a $\mathrm{N}$ [uestr]o $\mathrm{S}$ [eño]r se los alargue con la salud y vida que deseo. De casa oy 14 de di[ciemb]re de 640 .

$$
\begin{aligned}
& \text { V. 1. m. de V[uestra] M[erce]d } \\
& \text { Don Diego de Contreras [rubricado] }{ }^{41} \text {. }
\end{aligned}
$$

Los datos que tenemos de él después ya no se refieren para nada al teatro. En el año de 1648 solicita su ingreso en una Cofradia, la de la Santa $\mathrm{Fe}$, ubicada en la madrileña parroquia de San Sebastián:

En la v[ill]a de M[adri]d, a dos días de el mes de febrero de mil y seysçientos y quarenta y ocho añ[o]s, estando en su junta particular los s[eñor]es D. Joán Reçio, coadjutor de hermano mayor, consiliaris y demás oficiales, se leyó un memorial q[ue] dio el 1 [icencia]do Luis de Benav[en]te Quiñones,

30 Se hallan también en el volumen de sus poesías, ms. 3.799 de la BNM, fol. 98. Por ello sabemos que Benavente se las había pedido ya en verano de 1638. Para su relación con nuestro entremesista y otros versos que le dedicó, véase nuestro artículo "En torno a la Jocoseria", en curso de publicación.

40 Ms. 3.799 , cit., fol. $65 \mathrm{v} .^{\circ}$

41 Ibíd., fol. 67 . 
presvítero, en q[ue] pedia se le admitiese por congregante, y visto por la Junta su petiçión se determinó se reçiua por ser persona de loable vida y costumbres. $\mathrm{Y}$ hauiendo propuesto algunas cosas q[ue] no se pudieron ajustar por faltar muchos de los s[eñor]es consiliarios y ofiçiales, determinó la Junta $q[u e]$, en conformidad de lo dispuesto por las constituçiones, se avise a todos los q[ue] deben asistir q[ue] para la Junta q[ue] viene, q[ue] será a nuebe de este presente mes, se hallen a la Junta, pena de media libra de zera q[ue] con efecto haya de pagar y con apercibimiento $q$ [ue] se proçederá a mayores penas para la seg[un]da falta y a la terçera se borra y del libro de la Congregaçión [...]. Con lo qual se acabó la Junta y lo firmó el s[eño]r coadjutor. Ju[an] Recio S[ecretari]o, el 1[icencia]do

D. Gaspar de Escalada y del Castillo ${ }^{42}$.

$\mathrm{Y}$ en 1651, cuando parece que estaba totalmente alejado del mundillo dramático, olvidado quizá de aquellos cómicos a quienes él había surtido de entremeses y de aquellos comediógrafos a los que habia conseguido salvar o hacer lucir sus comedias, muere en la miseria más absoluta. Hombre modesto hasta el extremo, huye de las posibles honras mundanas y no se acuerda para nada de sus parientes toledanos, quizá con la excepción de su heredera, la abnegada doña María Turienzo, que le había atendido desde mucho tiempo atrás, cuidando de sus enfermedades, la causa que motivó su alejamiento del teatro.

Por su testamento de 17 de agosto de $1651^{43}$ sabemos que tenía devoción "a los gloriosos S[an] Joseph, esposo de n[uestr]a S[eñora] y mi padre $\mathrm{S}$ [an] F[rancis]co, S[ant]o Domin[g]o, S[an] Ant[oni]o de Padua y Arcanjel S[an] Gabriel" y que quiso ser enterrado "en la iglesia parroquial de $\mathrm{S}$ [an] Seuastián, en la capilla y entierro de los congregantes del S[an]to $\mathrm{Cr}$ [ist]o de la $\mathrm{Fe}$, de donde soy tal congregante, y supp[lic]o a todos los $\mathrm{s}$ [eño]res de la Congreg[aci]ón lo permitan, aunq[ue] indigno her[man]o y no mereçedor de tal honrra".

Pobre y modesto hasta el extremo, establece que sus testamentarios que “escusen pompa y aplausos del mundo por q[ue] dem[ás] de no tener yo posibilidad ni vie[ne]s ning[un]os, mi volun[ta]d es, aunq[ue] los hubiera, escusar aparato y banidades" 4 .

4. Acuerdos de la Congregación del $S$ [ant]o C [rist ]o de la $\mathrm{Fe}$. Libro segundo, 1647 1742, fol, 48. (Archivo parroquial de San Sebastián. Madrid.) Es interesante el folleto de Matías Fernández García, La Congregación del Cristo de la Fe y su capilla, Madrid, 1980, según el cual hacia 1648 muchos devotos ciudadanos deseaban entrar en la Congregación, fundada en 1632 , y parece que a nadie excluían.

43 Era nuestra intención reproducirlo aquí, pero cuando corregimos pruebas de este artículo nos llega el trabajo de María Luisa Lobato "El testamento de L. Q. de B.", en $B$ Com., 44, n. ${ }^{\circ} 2,1992$, págs. 253 a 259 , que lo edita también, y por ello prescindimos de hacerlo. La citada investigadora transcribe el nombre de la heredera del autor como "María Turienco".

4 Archivo de Protocolos, Madrid, n. ${ }^{\circ} 8.211$, años 1650-51, fols. 722-723. 
Son las palabras de un hombre sencillo que parece querer irse del mundo sin llamar la atención y sin causar el más mínimo revuelo. El, a quien tan buenos ratos debian tantos contemporáneos de todas las esferas sociales.

\section{Poesía.}

Benavente no fue muy amigo de escribir poesias. Ya hemos dicho que sus contribuciones a las Academias no son muy abundantes. Tampoco escribió versos para libros de amigos (a pesar de que a él si se los dedicaron) ni participó en justas literarias, con la excepción de una o dos, la celebrada en Toledo en 1609 y alguna otra. Sin embargo, si contribuyó a la Congregación del Cristo del Olivar con cierta frecuencia, por lo menos desde que perteneció a ella (¿1625?) hasta su muerte. Estas composiciones se conservan gracias a que fueron recogidas en sendas publicaciones de Martinez Grimaldo. En todas estas muestras de su poesia podemos apreciar el gran ingenio del entremesista, sus procedimientos humorísticos y, también, su habilidad para versificar. Como tienen un interés notable, hemos querido reproducirlas acompañadas de algún breve comentario.

En ellas aparece la vena jocosa y la vena seria de nuestro autor, algo que también se encuentra en su obra dramática, si bien no tan claramente diferenciado. Benavente se muestra festivo o no, pero siempre ingenioso y correcto desde el punto de vista poético. Utiliza recursos característicos de sus entremeses, como el empleo del rústico lenguaje sayagués, el equívoco, el retruécano, la deformación de palabras, los chistes típicos de sus bailes y entremeses, etc.

Toda su obra poética podemos decir que es "de circunstancias", en el sentido de que todos los poemas que escribió Benavente nacieron no de su propia voluntad, sino de un motivo que previamente le habian dado: la glosa de un verso famoso de entremés, la alabanza a San Ignacio o a la celebración de turno de los Esclavos del Santísimo. Benavente tendrá que ingeniárselas para componer sus poemas, serios o jocosos, a unos asuntos ya establecidos. Los temas que suelen aparecer tienen que ver con estos asuntos, como es lógico. Por una parte están los de contenido puramente burlesco, que corresponden a los poemas escritos para aquellas academias burlescas del Buen Retiro de 1637 y 1638 . Su fin suele ser la sátira leve contra las mujeres desdeñosas, las beatas o la fealdad de Coridón. Pero la mayor parte de las composiciones de nuestro autor tienen que ver con lo religioso, porque fueron actos religiosos principalmente los que le movieron a colaborar : la beatificación de San Ignacio o las celebraciones de la Congregación de la que era esclavo

Benavente se muestra en ellas profundamente cristiano. Muchas de sus 
composiciones tienen un tono "serio", $y$ apenas podriamos descubrir en ellas, si no lo supiéramos, la autoria del alegre entremesista. Tratan de los misterios de la fe, muy frecuentenente de Cristo hecho hombre para salvar a los demás, que se da a todos en la Eucaristía. Pero donde Benavente alcanza sus momentos mejores, según nuestra opinión, es en aquellos otros versos donde se da la vertiente "festiva" y aparecen rústicos, muy a menudo expresándose en sayagués, para tratar de describir lo que están viendo en la Corte: la iglesia engalanada, la procesión deslumbrante, el Rey, el lujo de los cortesanos, etc. El rústico sayagués, a pesar de su rudeza, va demostrando a los demás que gracias a su fe sencilla y a su amor a Dios es capaz incluso de compararse a este. De esta graciosa comparación para la que el rústico echa mano de sus escasos conocimientos rurales, surgen precisamente los mayores atractivos del poema. Generalmente el final suele ser el mismo: el rústico no entiende lo que ve, pero eso le ayuda a reafirmar más si cabe su propia creencia.

Son los graciosos equívocos del aldeano, sus comparaciones y exageraciones, lo que más llama la atención y nos recuerda los mejores momentos del Benavente entremesista: hay sustitución de nombres por razones significativas: "la reina Estera, / mujer de Cuajada o Suero": cambios de palabras con intención hiperbólica: "guardaelefante" por guardainfante"; calambur : "limonada" junto a "limo y nada"; alusiones tópicas como la de apartar las aguas del vino; referencias a la mala situación de la época: "vuestro pan se baja / no se suba el que se compra", "muchos he visto yo / que del aire se sustentan" (como unos ángeles están suspendidos del aire en la iglesia); paronomasias: "de gusto" / "de gasto"; dilogías, como la palabra "unto"; deformaciones burlescas: "plata gruñida" por "bruñida" (lo que le da pie para un gracioso juego de palabras, cuando sigue "del platero y quien la presta") 45 .

Una ojeada a su versificación nos demuestra que son los versos cortos, con el octosílabo a la cabeza, los que prefiere nuestro autor, en las combinaciones más usuales como el romance o la redondilla, aunque también escoja otras estrofas como el soneto en alguna ocasión ${ }^{46}$.

La primera composición que conocemos de él es el soneto a la Justa toledana de 1609, celebrada por la beatificación de San Ignacio;

45 Es interesante para todos estos 'detalles el libro de Bergman, tantas veces citado, y el estudio introductorio de Christian Andrès a su ed. de Entremeses de L. Q. de B., Madrid, Cátedra, 1991, en especial las págs. 33-38.

46 Estrofa rara en Benavente y generalmente usada para lo grotesco, como demuestra Bergman, op. cit., pág. 209. También es útil el trabajo de M. ${ }^{a}$ Luisa Lobato, "Tres calas en la métrica del teatro breve español del Siglo de Oro: Q. de B., Calderón y Moreto", en Homenaje a Hans Flasche, Stuttgart, 1991, pág. 117. 


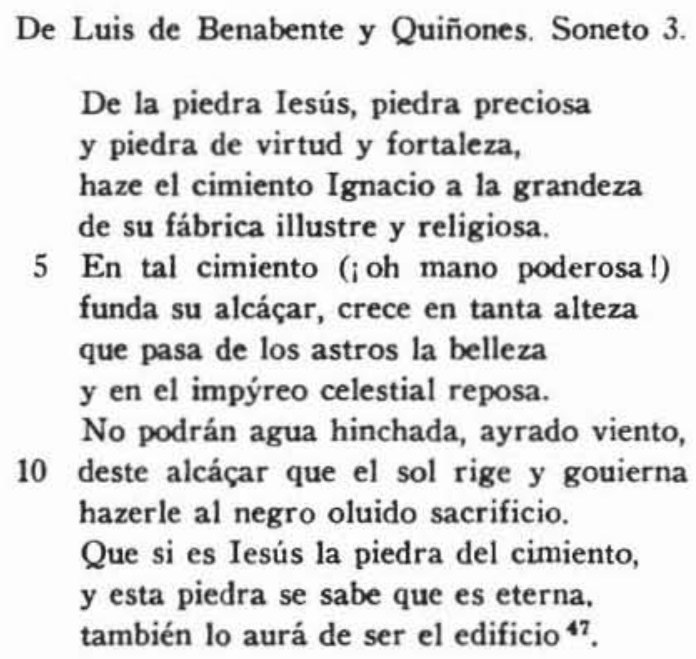

Benavente, a pesar de la opinión de Julio Milego, no participa en la Justa celebrada en Toledo en 1616, o al menos no encontramos ningún verso suyo en la obra que recopiló Pedro de Herrera ${ }^{48}$. Tampoco partició en la Justa poética celebrada en Madrid con motivo de la beatificación de San Isidro, el licenciado Toledano que sugiere Bergman pudiera ser nuestro autor, seguramente no es otro que Miguel Toledano, ya que en la Justa no se admitian seudónimos ${ }^{4}$.

Pero si encontramos sus versos otra vez en la Academia burlesca celebrada en Buen Retiro en 1637. El motivo al que escribe nuestro poeta no podía venirle mejor pues surgió de unos versos suyos y de un personaje de su entremés, Juan Rana. En el entremés de Los alcaldes encontrados, sexta parte, pronuncia el alcalde Lorenzo: "Beati quin dole me moriunto, que las beatas no tienen unto" 50 . La frase debió de hacer fortuna y se convirtió en tema de composición. Asi surgió uno de los asuntos del certamen:

Doçe redondillas que digan la raçón por que las beatas no tienen vnto; y si basta la opinión del Doctor Iuan Rana para que se crea. Redondillas de Luis de Venabente.

47 La justa literaria está recogida en el libro de Mateo Fernández Navarro, Floresta espiritual con un auto sacramental nueuo, Toledo, 1613. El poema ocupa los folios $167 \mathrm{r}^{\circ} \mathrm{y}$ v.

48 J. Milego, El teatro en Toledo durante los siglos XVI y XVII, Valencia, 1909, págs. 99-100.

40 Véase la $o p$. cit. de Bergman, pág. 51, nota 21.

so Cotarelo, pág. 681a. 
Juan Rana, ynsigne doctor. altercando çierto punto dixo que no tenian vnto las beatas de el Señor.

5 ¿Por qué, se le preguntó, no tienen vnto las tales, siendo gordas naturales? $Y$ él respondió: porque no. Tan bien fundada razón

10 (que no ay otra que lo sea) basta para que se crea deste doctor la opinión. $\mathrm{Y}$ siguiéndola diré el porqué no tienen vnto;

15 algo grueso es el assumpto, mas yo le adelgaçaré.

Las que dan en embeatarse engordan de casa en cassa, comiendo amás de la tassa

20 y bebiendo hasta arrobarse. Pues si crian tantas pellas que a estar ympedidas bienen, ellas el vnto no tienen, que el vnto las tiene a ellas.
25 Si dan por el abstinençia, menos vnto an de tener porque cada vna ha de ser vn congrete de Valençia. $Y$ destas la más perfeta

30 que querian aberiguar, en empeçando a rrodar rechina como carreta. Alto responde y mohina al que auerigualla trata,

35 luego la dicha beata no tiene vnto, pues rechina. Sin esto no ay entender que den de balde vn tostón, pues las que $\tan$ secas son

40 ¿qué vnto pueden tener? Quisiéronme sobornar porque callara este punto, mas como no tienen vnto no me pudieron vntar.

45 Perdónenme las del gremio, que a oýr mis coplas se juntan, que, pues ellas no me vntan, me quiero vntar con el premio ${ }^{51}$.

También colaboró Benavente en el certamen celebrado un año después, en 1638 , en el mismo sitio. Otro motivo burlesco guió sus versos ahora:

Perdióse infiel a lo hermosso por una fea muger

Coridón, y echó a perder el delito más airoso.

5 Qué gusto de hacerle feo su diligençia barata porque fuesen de una dacta el delito y el empleo. Yo no sé qué le mouió

10 a haçer $\tan$ fea su culpa donde aun es fría disculpa "el diablo me tentó". Ello muy bien pudo ser, si lo diçe Coridón,

15 mas para tal tentaçión mucho diablo es menester. Si hiço la ocassión la herida, él es en tales cuidados de los más ocassionados

20 hombres que e uisto en mi uida. Que si el copete promete dicha al que asirle desea $\langle s\rangle$,

51 Academia bvrlesca en Buen Retiro a la magestad de Philippo Qvarto el Grande /manuscrito de 1637/. Ed. dirigida por Antonio Pérez Gómez, Valencia, 1952, págs. 62 64. Se trata de un poema reproducido con algunas variantes en el ms. 2.244 de la B. N.

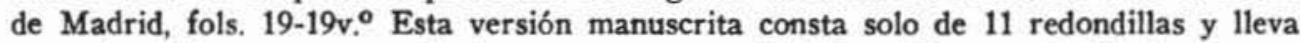
a continuación otro poema al mismo tema que escribió Juan Navarro de Espinosa, censor de comedias y autor de poesías varias. Este mismo poema se halla impreso en las Poesias del Dr. Salinas (Sevilla, 1869 II, pág. 206), pero esta atribución carece de fundamento según ya ha aclarado Antonio Carreira, "Nuevos textos y viejas atribuciones en la lírica áurea", Voz y Letra, I, 1990, pág. 109. 
esta es ocassión tan fea que no tiene ni aun copete.

$25 \mathrm{Y}$ en pérdida declarada sin ceuo de hermoso echiço, Coridón perdone, que hiço mui gentil coridonada; que aunque echó con mano franca

30 todo el rresto en el tablero, si jugara un siglo entero no auenturaba una blanca. Mas porque esta verdad pura no cobre fuerça bulgar

35 se escureçe a sí por dar más realze a su blancura. Diciendo con pecho fiel (tanto la pasión le muebe) que es ella la misma niebe,

40 siendo el mismo Carrión él $\mathbf{Y}$ por Dios que ser pudiera quando su fiereza admiro ella fiera del Retiro $y$ él rretiro de la fiera.

45 No le afees, déxale, bulgo, rrepara y berás que el puede afearte más porque tiene más con qué. Mira que diçiendo está

50 al que en murmurar se emplea : yo no e echo cosa fea que hecha se lo estaua ya. Luis de Benauente ${ }^{52}$.

En el códice manuscrito 3.773 de la Biblioteca Nacional se recogen varios versos de Academia, algunos relativos a un certamen celebrado justamente en el Retiro en 1638, y aunque no todos los versos en él recogidos pertenecen a dicho certamen (hay versos de Academia algunos años anteriores, como ha aclarado la profesora Bergman ${ }^{53}$ ), encontramos varias contribuciones atribuidas a nuestro escritor, entre ellas un romance que siempre ha pasado como de Quevedo, el que se inicia "Viejo verde, viejo verde" ${ }^{4}$. También otro poema que dice así:

\section{Romanze de Luis de Benauente.}

Pardiez, ermana Marica, no ssé qué diablos me tengo, que mientras más me persiguen más apretado te quiero.

5 Bite el disanto en el bayle y sin reparar en ello, bienes $\mathrm{y}$ tomas, $\mathrm{y}$ ¿qué hazes? Mírasme y déjasme muerto. ¿Parézete bien, Marica? 10 ¿Yziérase en Arjel esto, cojer los hombres seguros y pegarles pan de perro ${ }^{55}$. Pero, si no te conozen, por que no te compren quiero

15 dezir tu nombre más claro, Marica, enbido mi resto. La caussa de mi afición es cuando más se acredita de mi bolsa mariquita,

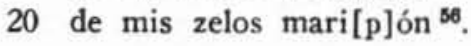

52 Biblioteca Nacional de Lisboa, ms. FG 3.788. Da cuenta de su existencia $\mathrm{H}$. E. Bergman, en "El Juicio final ...", cit., pág. 560.

53 "El juicio final ...", cit., págs. 551-610.

54 Para todo lo relacionado con este poema y la conexión entre Quifiones y Quevedo remitimos al libro del maestro Maxime Chevalier, Quevedo y su tiempo: la agudeza verbal, Barcelona, Crítica, 1992, págs. 220-226. También a nuestro estudio citado "Un romance de Quevedo atribuido a Quiñones de Benavente ...", en Manuscrt. KAO.

ss En el entremés famoso de nuestro autor, Los sacristanes burlados, se puede leer: “-Estos pícaros me enfadan. / -Pues pégales pan de perro." (Cotarelo, Colección, pág. 618b.)

so Ms. 3.773, fol. 18. Ya hemos sugerido que es más probable que el último verso 
El manuscrito 3.799 recoge varias poesias de don Diego Contreras, amigo y pariente de nuestro autor, según leemos, que en 1640 debía formar parte con Benavente de una academia, probablemente la celebrada en casa del contador Agustín de Galarza. Un asunto de esa academia debía de ser componer un poema dedicado a este don Diego Contreras pidiéndole dinero, porque encontramos otros dos poemas, además del que transcribimos a continuación a este asunto, uno de Bocángel y otro de un tal Antonio Sánchez. Dice asi el de Benavente, que no debía de ser sólo literatura, a tenor del billete que le acompaña y que arriba hemos reproducido:

De Luis de Benabente, que embió este romanze pidiendo unos dineros.

Señor d[on] Di[eg]o Contreras, mi amigo, ques más que deudo, aunque por bentura mía ambas cosas en bos tengo.

5 Cuyo agrado y cortesía, cuyo delicado injenio en poca edad os dan nombre de cortesanaço biejo. Vos, que os serbís de las musas

$10 \tan$ acaso $y \tan$ a tiempo que umanándoos a tratarlas no os an perdido el respeto. Vos, que honrrando mis escritos me abéis dado en beinte bersos

15 más fama que en treinta años alcanzaron todos ellos. $\mathrm{Y}$ bos, en fin, tan preçiado de que franco y limosnero el que llega a buestra puerta

20 no conozca al desconsuelo. Escuchad en confesión a este aficionado buestro, porque los pobres honrrados se alientan con el secreto.

25 Yo, el hombre más zelebrado que se a bisto en nuestros tiempos, pues todas mis pretensiones dan conmigo de zelebro, sirbiendo a Su Majestad

30 diez $y$ nuebe años enteros en las fiestas que an causado su real entretenim [ien] to, al $\mathrm{s}$ [efio] $\mathrm{r}$ protonotario abrá dos meses y m[edi]o

35 pedi una ayuda de costa y él me prometió de haçerlo; mas, como esto del comer es mandamiento de apremio y en dilatándolo un día

40 matan a un hombre por ello, y como las deudas mías no saben si yo pretendo, si no enbían un notario con un precepto solbendo,

45 mientras me haçen merçed prometóos, s[eño]r don $\mathrm{D}$ [iego], que un real ¿qués un real? ni aun una blanca poseo. Diréis que en qué se an gastado

50 los çiento y quarenta vuestros; a qüenta del alquile[r] se los llebó un fraile lego y agora me bengo a allar con pascuas y sin dineros.

55 Mirad con quién y sin quién para pagar lo que debo mátanme por lo que resta $y$ asi umildem[en]te os ruego $\mathrm{p}$ [ar]a pagar y comer

60 me prestéis otros docientos. Ya bistes cómo cumpli, aunque en dilatado tiempo, con los treçientos pasados, que eternam[en] te agradezco.

65 Estos no serán así, pues $\mathrm{p}$ [ar]a pagallos tengo

acabe con "maripón", en lugar de "maricón". Véase nuestro trabajo cit. "Un romance de Quevedo atribuido a Q. de B.". 
un libro que saldrá a luz

a más tardar por enero.

Tengo el ayuda de costa

70 que presto surtirá efeto

y en casa os tenéis la prenda,

si no quedáis satisfecho.

Con aquesto me hacéis hombre ymitando al mismo çielo,

75 que haçe los hombres de nada y resuçita a los muertos.

Doleos de mí, ansí beais entre feliçes suçesos

coronada vuestra mesa

80 de hermosos ánjeles nietos.

No permitáis que esta pascua

tenga $\tan$ poco remedio que no se le pueda dar a una madre a quien benero.

85 Si no, mirad en mi estado, como tan grande sujeto, que pobreça no es bileza con birtud y sufrim[ien]to.

Pero donde Benavente colaboró con más asiduidad fue en la Congregación de Esclavos del Santísimo Sacramento del convento de Santa María Magdalena. Encontramos varias de estas composiciones en Ramillete de las flores (Madrid, 1650), que recoge poesías de varios ingenios de esta congregación que se cantaron en las celebraciones que se hicieron ese año en el convento de Santa María Magdalena ${ }^{5}$. Varias de ellas se refieren a Benavente, concretamente la primera, un romance, abrió el domingo por la mañana "al dulce concento ( $\mathrm{sic}$ ) de la música". Para el colector dicho poema era "tan hijo de su policía como de su elegancia":

\section{Romance del Licenc[iado] Lvis de Benavente en lenguaje sayagués.}

Contaua vna labradora

al cura de Zalamea

de la suerte que vio a Dios triunfante en la Madalena.

5 Yo passaua, señor cura, acauso por vna igreja de aquella santa que a vnturas sanó de vna gran dolencia. $\mathrm{Vi}$ gente y coléme dentro,

10 a pesar de vna belleza que con vn guardaelefante tenía vna tranca puesta. Pasméme en entra[n]do y dixe: Iesús, con tantas riquezas,

15 (aunque España llore duelos ¿cómo quiere que la creigan?). La igreja era toda de oro $i$ el altar magino que era todo de prata gruñida

20 del pratero y quien la presta.
Salian de las paredes tantos braços con hachetas que dixe: Con tantos braços qualquiera rico se huera.

25 Bestidas de azul y prata auía muchas tabretas con cuerpos de santos que a su costa lo sustentan. De prata eran pero muchos

30 y dixe: Más me semeja la fiesta de Todos Santos que no del Cuerpus la fiesta. En otros ramos de frores con pies de prata y por huerça

35 tendrían sobido olor quien tales raizes hecha. Vnas lánguimas auía con tal vertú, que a qualquiera que las columbraba hazia 40 estirar entrambas cejas.

57 El propio Martínez Grimaldo recogió en 1657 otra vez estos versos en su libro Fundación y fiestas de la Congregación de los indignos esclavos del Ss. Sacramento, Madrid, 1657. Citamos las variantes de esta ed. en nota. 
En vna barca que algunos Góngora $\operatorname{dix}[e] r[0] n$ que era estaua Cristo embarcado, triste de mi si se ausenta.

45 Yo le dixe: Cristo mío, si os partís al cielo sea $\sin$ las joyas, que dexáis los comissarios a puertas. Que fro[n]tal, gradas, jarrones,

50 huentes, saluas, albahaqueras es vna gomia y no ay rincón que prata no sea. En somo de todo estaua vna hermosa tarjuleta
55 y en ella pintado un crabo que le ciñe vna culebra. Pescudé qué denifica y dixonme que era emprenta y mimbre de vnos Escrauos,

60 que estauan hendo la fiesta. $\mathrm{Y}$ yo respondi : La dicha que tuuo la reyna Estera, muger de Quaxada o Suero, $\tan$ buenos escrauos tengan.

65 Vaya a verlo, señor cura, y por si acaso le aprietan lléuese el manteo viejo, no me maldiga a la vuelta ${ }^{\text {s8 }}$

La segunda la introduce asi el editor, Martínez Grimaldo:

No se apvra la vena ni la devoción del licenciado Luis de Benauente, y assí repitió los conceptos con su acostumbrada agudeza, haciendo puente de la rustiquez de las vozes para la doctrina de los conceptos.

En esta ochaua del Corpos

del Señor San sacramento

quiso alumbrar mi ignorancia vn doto $\mathrm{y}$ deuoto crego.

5 Él (según lo que dezía)

tendría lindo pergeño, mas por mucho más que dixo yo le entendí mucho menos. Díxome del Hijo y Padre

10 tan ralos concebicetos que por no quedarme a escuras me acogi a la luz del Credo. El dixo que el Señor Dios allá se estaua en sí mesmo

15 holgándose como vn Padre sobre todo y nada a vn tiempo. $\mathrm{Y}$ diz que apartó las aguas de las aguas, y yo entiendo que apartarlos oy del vino

20 huera otro milagro nueuo. También me dixo que Adán del limo y nada fue hecho.

58 Ramillete de las flores que del iardin del ingenio, regado con el rocio de la devoción brotaron algunos de los elegantes $y$ devotos congregantes del San $[t]$ issimo Sacramento. Para cantar svs glorias en las festividades que este año de 1650 ha celebrado su Esclauitud en el Conuento de Santa Maria Madalena de esta corte. Atadas por D. Ioseph Martínez de Grimaldo...//s. 1./,/s. a./. El poema se encuentra en las páginas a lápiz 248-249.

$\mathrm{La}$ ed. 1657 recoge algunas vars. como "Magdalena" en el v. 4; "guarda elefante" en el v. 11; "Corpus" en el v. 32 ; "a caso" en el v. 66 , aparte de otras menos significativas. $\mathrm{Y}_{\mathrm{a}}$ hemos señalado que este poema se inicia igual que el de Quevedo titulado "Labradora haciendo relación en su aldea de todo lo que había visto en la Corte", que comienza: "Contaba una labradora/al alcalde de su aldea" (Ed. Blecua, 1971, págs. 119. 24). También en este poema de Quevedo aparece el lenguaje rudo de los rústicos que confunden unas palabras con otras, pero no llega a los juegos idiomáticos que introduce Benavente en el suyo. Un rasgo más en la relación entre el gran entremesista y don Francisco de Quevedo. El poema fue imitado bastante servilmente por dos poetas ocasionales poco después de que lo escribiera Quevedo, pero Benavente no plagia, solo toma el primer verso y lo deforma a lo burlesco, según comentamos en nuestro trabajo citado ("Un romance de Quevedo..."). 
$¿$ Pues, si hue de limonada, cómo tuuo carne y huesos?

25 Assentó q[ue] Adán y Esgueua hueron casados perfetos. ¿Pues, cómo sobre vn bocado tuuieron $\tan$ grandes preitos? Que lloró Adán y Dios Padre

30 se apracó, y saber deseo cómo, si no estaua ayrado, echó por la boca verbos. Nacido y pequeño, dixo que vino Christo, y no entiendo

35 cómo vino tan nacido el que vino $\tan$ pequeño. ¿Cómo es la Persona que haze y la que padeze a un tiempo? $Y$, si es su nombre Iesús,

40 ¿cómo es Nombre siendo Verbo? Dixo $q[u e]$ es Dios sano $y$ tiene cinco huentes $y$ antes de esso tomó en vn campo la zarça y sudores en vn huerto.

45 Más dixo: q[ue] es buen amigo, qua[n]do sé que en forma puesto es Persona de dos caras, diuina y humana a vn tiempo. Que es Dios muy rico, me dixo,

50 y vna vez que dio pan, luego dixo: "Ya no tengo más que dar a mis compañeros." Diz que es poderoso y huerte y el más fraco presbytero

55 con solas cinco palabras da con todo El en el suelo. Que es Dios cuerdo y graue y anda por essas calles en cuerpo, y sin her más deferencia

60 trata con brancos y negros. Que Christo es muy sosegado, y sé yo que en cierto tiempo porque pagasse vn pecado en vn huerto le prendieron.

65 Dixo que es gran sacerdote, quando se intitula El mesmo el gran Dios de las batallas. ¿Pues, cómo es soldado y es crego? Que Dios es espiga y es vid,

70 mas yo lo pranto $y$ lo siembro y son cosas deferentes $y$ no vna en vn sugeto. Cosas son estas, mi Dios, no de mi corto pergeño,

75 más mientras más rebesadas a pies juntillas las creigo. Escrabos de su familla, espricadme estos misterios, Pan por pan, Vino por vino,

80 sin andar por viricuetos. Que yo prometo en retorno de ser vuestro pregonero, pubricando las grandezas que en esta ochaua auéis hecho ${ }^{50}$.

\section{Y la tercera:}

Otro romance del licenciado Lvis de Benauente.

¡A, Señor, el de lo branco! Perdonad mi luenga costa, mientras yo y los que me escuchan nos entendemos a copras.

5 Que os tengo de resquebrar, aunque sea cosa impropia que vn hombre de gallaruça se meta entre tantas gorras. Yo os hago vna remenencia,
10 dos y tres, vna en pos de otra porque, aunque sos vno, diz que se la deuo a tres personas.

Assi nos lo sermoneó el preste, que en igual groria

15 sos vno y tres, que yo no lo lebanto de mi cholla. Diz que sos tan apacibre que, aunque a bocados os c[o]ma

so $O p$. cit., fol. 250. La versión que se publica en 1657 tiene algunas variantes dignas de mención, la diferencia más importante es que le falta la estrofa quinta, y, aparte de otras meramente ortográficas, hay que notar que registra "presona" por "persona" (vv. 37 y 47 ). 
qualquier pobrete, si lleua

20 gracia, nenguno os enoja.

¡Qué deferente so yo, que si alguno me ocasiona le do al diabro, aunq[ue] me trayga más gracias que tiene Roma!

25 Pero está la deferencia en que vos heis vuessas cosas como quien sois, pero yo como quien so, que esso bonda. Muy mal hazen las ánimas

30 que con vos no se desposan, pues que no puede acabarse iamás el pan de la boda. Que allá diz que (no sé dónde, que so endebre de memoria)

35 cinco mil hombres hartaron dos pezes y cinco tortas. $\mathrm{Y}$ otra vez vueso poder ell agua en vino trastorna, milagro bien al rebés

40 de los que en la tierra se obran. Oy pienso que cumprís años y os bestis de brancas joyas, como quando en el tambor os rellenastes de groria.

45 Sie $[\mathrm{m}]$ pre hueron vuesas manos para darme la vitoria muy liberales conmigo, consigo muy manirrotas. Vuesas riquezas hazéis

50 a todo el mundo notorias, sin que de nadie os guardéis con estar siempre en custodia. Pues sois Pan, dadme esse pan, assí la torrezna zona

55 y la cinta más elada por su Autor os reconozca. $\mathrm{Y}$ otra cosa he de pediros, záfil, que no enfecultosa, que, pues vuestro pan se baxa,

60 no se suba el que se compra. Más dixera de lo dicho, mas es una Babiloña habrar de vos, porque se confunden las lenguas todas ${ }^{60}$.

El mismo Martínez Grimaldo recogió unos años después estos y otros poemas en un libro de más enjundia que para conmemorar el cincuenta aniversario de la fundación de la Congregación habia hecho. En él recoge estas contribuciones que atribuye a Benavente en determinados años. Las fechas (que según Grimaldo oscilan entre 1625 y 1652) no son muy fiables, sí orientativas, porque de los tres poemas reproducidos más arriba como de 1650 dos los edita ahora como de ese año, pero otro lo escribe en un año muy anterior, 1625. Dicen asi :

Admirable romance del licenciado Luis de Benauente, todo al misterio y todo a la admiración.

Oy un firme enamorado mesa franca haze en el cielo $\tan$ a costa de su hazienda que le han de vender por ello.

5 Es vn Rey, a quien su Padre engendra en su entendimiento, publicándole por Hijo, Hic est Filius meus dilectus. Panal le admira Sansón,
10 Elias, pan ceniciento, Israel, blanco maná, Moysés en la zarça, fuego. Iuan, aquella voz de Dios, le llama manso cordero,

15 Qui tollit peccata mundi, señalándole su dedo. El águila le contempla vn libro con siete sellos

* También la versión publicada en 1657 tiene algunas variantes, significativas, como "presonas" (v. 12), "Costoria" (v. 52) y "luengas" (v. último). 
siendo al principio palabra,

20 Et in principium erat Verbum. Dize que ha de sustentarnos pues nos da palabra de ello, coged a Dios a palabras, Hoc est enim corpus meum.

25 Manda que vengáis de boda y al cumplir este precepto Probet autem se ipsum homo, que Dios auisa primero.

Sin cruz no intentéis sentaros
30 que aun a sus cercanos deudos (seuero) dixo: Potestis bibere calicem meum? Llegad al dulce vanquete, limpios, humildes y ciertos,

35 que os ha de amar hasta el fin, In finem dilexit eos.

Llegad, amigos, llegad, que mientras estéis comiendo todo el cielo os cantará

40 Tantum ergo sacramentum ${ }^{61}$.

Los de la música hizieron su festejo a celebridad tan grande y el ingenio del licenciado Luis de Benauente cantó en sayagués estilo y en concepto remontado el romance que se sigue.

Señor vestido de branco, como en mi vida estorié, pardiobre que no sé cómo he de habrar con su mercé.

5 Mas, aunque nací en Sayago y vos, Señor, en Belén, de una misma tierra somos, que yo lo sé sin saber. Entre güeyes y entre mulas

10 en la mía me crié y vos abristes los ojos entre una mula $y$ un güey. Pastor soy, si soys pastor, en pan trato, y vos también,

15 bien puedo habrar llanamiente pues vuestro igual vengo a ser. Noticia de vos tenía $y$, aunque mis ojos no os ven, el alma me está diziendo

20 que lindos hechos tenéis. Con essa paz que mostráis en essa nieue en que ardéis que soys mi Dios mi fe me dize y no me engaña mi fe.

25 Bien lo supo vuestro primo, el choquillo de Isabel, pues ante de auer nacido saltó y bayló de pracer. No hazéis nada sin misterio,

30 que aunque tan cándido os ven,
Dios es mi padre y el vuestro, qué gran calletre tenéis. Soys gran letrado y ninguno de $\tan$ lindo parecer,

35 pues como aquel que las hizo todas las leyes sabéis. La natural para Adán, la escrita para Moysés $y$ en estos tiempos dichosos

40 nos dais de gracia la ley. Y dando de vuestra hazienda a los pobres de comer los dais más gracias que el Papa y más perdones que el Rey.

45 Entre tantas marauillas la que más me admira es cómo sin dexar la capa estar en cuerpo podéis. También me espanta, Señor,

50 de que amigos que tenéis ellos os beban la sangre y que vos los queráis bien. Mas cómo, Señor, me pongo con mi simple rustiquez

55 a deziros tan mal dicho lo que vos $\tan$ bien sabéis. Vos a vos os alabad con vuestro inmenso poder. $\mathrm{Y}$ agora quedaos con vos

60 pues con Dios os quedaréis ${ }^{62}$.

61 Joseph Martínez de Grimaldo, Fundación y fiestas de la Congregación de los indignos esclavos del Ss. Sacramento qve está en el religioso convento de Santa María Magdalena, Madrid, 1657, fol. 60. De 1628, según el editor.

62 Ibíd., fol. 62 . De 1630, según el editor. 
Alegre tan gran dia esta festiuidad el ingenio del licenciado Luis de Benauente con la letra que se sigue.
Albricias, que llueue al iusto del cielo vn dulce maná que gustado da la vida, que gustado muerte da.
5 Gran nouedad. Intacto está en vna oblea, cándido está en vn cristal, tan Dios como lo es su Padre, tan hombre como el que más.
10 No ay que dudar.
Tú que lo ves, fe divina, aunque sin ojos estás, acertando siempre al blanco de su infinita piedad.
Viendo nuestra gran miseria, baxó de su alcázar real y de león de venganças se nos conuirtió en Manjar. Luchó con él el amor y su fuerça sin igual en la tierra disfraçado le puso en forma de pan.

15 Tú lo dirás.

20 Gran caridad.

25 Lindo disfraz.

\author{
Combidando está con ello \\ y $\tan$ barato lo da \\ que solo de que lo quieran \\ se paga su gran bondad.
}

30 Suma piedad. También nos ofrece vino, que arroyos manando está de aquella vid verdadera que explica el águila Iuan.

35 No ay más verdad. Pero mire cómo viene el que lo llega a gustar, y assí beba de aquel cáliz, y assí coma de aquel pan.

40 No ay que ignorar.

En aquel círculo breue tan gran comida nos da que con ser $\tan$ poderoso no le queda más que dar.

45 ¡Qué gran bondad! Agradecidos esclauos, la mesa que le adornáis con tantos gastos, la paga los excede mucho más.

50 Dicho se está ${ }^{\text {es }}$.

Y será bien que alegre lo solemne de la processión vna misteriosa letra que para ella escriuió el licenciado Luis de Benauente.

Pelicano amoroso, que con el pecho abierto, a costa de tu sangre, sustentas tus hijuelos.

5 Fénix amante y solo, que en medio del incendio, muriéndote por todos, renaces por ti mesmo. Pastor, que en tu rebaño

10 con superior acuerdo pudiendo ser león quisiste ser cordero. Tu amor es grande, pues por él te has hecho

15 Fénix, Pastor, Pelicano y Cordero. Enigma no acertada de humano entendimiento, hasta que a su grandeza la fe le corre el velo.

20 Vida que da la muerte, bien que en mal le concierto, siendo (por culpa mía) contrarios los efectos. Panal que de la boca

25 del león procediendo, en sombra figuraste tan alto SACRAMENTO. Tu amor es grande, pues por él te has hecho

30 Panal, Enigma, Vida y sacramento. Galán tan cortesano siendo, Señor inmenso,

os Ibíd., fols. $69 \mathrm{v}^{\circ}$ y 70 . De 1635 , según el editor. 
que no mirasen puntos, como en el mundo vemos.

35 Pues con llaneza suma con los blancos y negros sales a pasearte por las calles en cuerpo. Trigueño estás del sol

40 ¿ mas qué mucho, sol bello, si es morena la madre que el Hijo sea trigueño? Tu amor es grande, pues por él te vemos

45 Cortesano, Galán, Llano y Trigueño. Hombre, pero tan hombre que a la vista de vn pueblo (clauados pies y manos) venciste los infiernos,

50 Dios, que sieruo pareces, pues por quitar los hierros de tus propios esclauos a ti te los han puesto.

Señor, que agradecido

55 oy de $\tan$ gran festejo, prometes a quien le haze por cada vno ciento. Tu amor es grande, pues por él tenemos

60 Dios, Hombre, Agradecido, Señor, Sieruo. Pan, que al mundo saliste, del intacto granero, adonde te encerraste no cabiendo en los cielos.

65 Dios, Hombre, Amante y Pan, si como Dios te vemos, si eres, como yo, hombre y como pan sustento, tu amor es grande, pues con él tenemos

70 Hombre, Sustento, Dios, Pan y Granero ${ }^{64}$.

Prosiguió el licenciado Luis de Benauente los primores empeçados para el festejo desta Octaua con el romance que se sigue, lleno de ternuras y de misterios.

De aquel círculo de nieue

al cándido resplandor los rayos de mil en mil se le cayeron al sol.

5 ¡O qué de misterios hallo en tan milagrosa acción! Endiosado lo que es hombre, humanado lo que es Dios. Con sus deseos anduuo

10 tan licencioso el amor que a material forma humana diuina essencia abreuió. Este es el Maná de quien tan mal el hebreo vsó,

15 el que en la zarça Moysés y Iuan sobre el libro vio. Cordero el vno, que quita del mundo las manchas oy; mysterios el otro, que arde

20 sobre el más limpio verdor. Este es aquel, cuyo dedo el Decálogo escriuió, cuyo antiguo testamento moderna firma borró.
25 Aquel es que, de Iudá fuerte y temido león, enrizó la greña a quantos blando después alagó. Aquel es que vio Ezechías

30 en carro ardiente y veloz discurrir del viento leue tanta espaciosa región. Aquel es que en la serpiente de metal se figuró,

35 bacío entonces prodigio y lleno de gracia oy. $\mathrm{Y}$ al fin es aquel racimo que con sacrílego error en el lagar de la Cruz

40 torpe el iudío exprimió. Pues a $\tan$ fácil bocado se reduxo tanto Dios, desátese el pecho en llanto y en alabanças la voz.

45 ¿Qué disfrazes son estos en que andáis, mi Dios? Mátenme si no anda por aquí el amor ${ }^{65}$.

(4 Ibíd., fols. $78 \mathrm{v} .^{\circ}$ y 79 . De 1642 , según el editor.

6s Ibíd., fols. $95 \mathrm{v} .^{\circ}$ y 96 . De 1649 , según el editor. 
Entre otros motetes con que festejó la música tan graue y deuota funcción se cantó el romance que se sigue del licenciado Luis de Benauente en estilo sayagués, con que se feneció dichosamente la Octaua deste año.

Oy diz que sale de casa el señor San Sacrame[n]to a regozijar los sanos y a consolar los enfermos.

$5 \mathrm{Y}$ diz que sale con él su Congregación de cregos, las camisas por de huera y los sayos por de dentro. En cuerpo y sin caperuças

10 le acompañan todos ellos, mas ¿qué mucho, si su amo viene en cuerpo y descubierto? Con campanillas y cruzes Sebastián le haze festejos,

15 porque vn pobre asaetado no tiene otros instrum[e]ntos. No se deshilachará, Rey, la processión por lo menos, que la traen muy encerada

20 la deuoción y el respleuto. La igreja y la calle están como de assí me lo quiero: todo seda por de huera, todo oro por de dentro.

25 iQué lindo que está el altar, qué verde, florido y fresco! De gusto a los que le miran, de gasto a los que le hiziero[n]. , Oigan, oigan, que lle canta[n]
30 la lletra del Tantom Ergo, vna vejez que a mill años que la saben en mi puebro! Pardiez que se desgaznata[n] estirando los piscuezos,

35 los que chillan encia arriba, los que roncan encia el suelo. Señores, ¿qué podrá ser que teniendo $\tan$ bue [n] preyto lo meten todos a vozes?

40 Pero son vozes del cielo. Vn crego viene amosca[n]do con vn vaso $\mathbf{y}$ vn salero y ahumando la procición, ninguno se enoja de ello.

45 Par Dios, q[ue] viene ya él $y$ aqueste no es juramento, que pardiós q[ue] está par Dios y a su diestra en alma y cuerpo. No importa[n] essos disfrazes,

50 que au[n]q[ue] ya ho[m]bre os co[n]te[m]pro os tengo reconocido por Dios viuo y verdadero. Vna enigma o cosa y cosa quiero proponer, mi dueño,

55 que en q[ue] me la acierte[n] todos está del mundo el remedio: ¿qués es cosa y cosa, ma[n]cebos, que cabe en la obrea y no cabe en el cielo? ${ }^{66}$.

Bien será que la música para entretejer con su dulze melodía este discurso breue le sazone con los conceptos del licenciado Luis de Benauente en sayagués estilo y en deuoto metro.

Voto al sol, q[ue] estó atordido, o créiganme o no me creiga[n], de ver la fiesta que hazen oy en esta santa igreja.

5 Tiénenla toda tan lumpia, tan garrida y $\tan$ compuesta que está como los espejos, como dizen en mi tierra. Tan crara y tan rellociente, 10 que qualquiera q[ue] entra a verla como en cristalino espejo se puede mirar en ella. Han puesto los comesayos, despreciando el oro y seda,

15 colgaduras de cristal, gran gala si no se quiebra. No sé cómo está el frontal hecho, ni de qué manera, que anda tanta gente dentro

20 como estamos acá ahuera.

Ibíd., fols. 101 y 101v..$^{\circ}$ De 1649 , según el editor. 
El se compone, a mi ver, de arroyos, frores y yeruas, sin que las pisen ni toquen la gente que dentro encierra.

25 El preste diziendo missa (como suele) a espaldas bueltas le vemos todos la cara sin que tuerza la cabeça. Otro preste tiene enfrente

30 que sus acciones remeda y él lo sufre aunque lo ve, yo al menos no lo sufriera. El coro, rejas y monjas, que están al pie de la igreja,

35 oy $\sin$ romper la clausura se han puesto a la cabeçera. Ay vna groria ¿q[ué] es groria? Ver que vna groria supuesta viuiéndola el Rey de groria

40 la haga groria verdadera. En lugar de candeleros, están teniendo las velas alados seraphinicos sin pies ni manos que tengan.

45 Diz que los sustenta el ayre, ni me admira ni me eleua, que muchos he visto yo que del ayre se sustentan. En toda mi vida he vido

50 tramoyas con tal grandeza, $\tan$ sotil juego de manos, tan costosas agudezas. $\mathbf{Y}$ todo en gordo he sabido que son los que haze[n] la fiesta

55 quatro escrauos $q[u e]$ vn bocado solo de pan los sustenta ${ }^{67}$.

Vn papel del licenciado Luis de Benauente ha de hazer agradable diuersión a este discurso.

Oye, sefior emboçado, ¿ para qué es esse disfraz?, que le conozco, por Christo, aunque se me esconda más.

5 Que aunque solo no penetro esse cándido cendal, la fe me ha contado todo el hecho de la verdad. Bien sé que viene por mí

10 desde su antiguo solar a hazerme saber que somos deudos por parte de Adán. Que dize que soy su alma, su descanso y su solaz

15 y que los amores míos la vida le han de costar. Porque desde doze años tan perdido por mí está que sus padres en tres días

20 no le pudieron hallar.

También sé que si le pago su amor con fee y co[n] lealtad que se dexará vender por tener más que me dar.

25 Que me dará la comida con tanta puntualidad que a trueco que no me falte a sí mismo se dará. Que se quedará en mi tierra

30 ajustando a mi humildad lo sumo de su grandeza para podernos gozar. $\mathrm{Si}$ acierto a caerle en gracia, enamorado galán,

35 no tengo más que pedir ni aun él tiene más que dar ${ }^{88}$.

Este poema puede servir para resumir esa faceta de hombre sencillo y creyente, que también conviene al entremesista, y de poeta correcto que siempre tuvo Luis Quiñones de Benavente.

67 Ibíd., fol. 122. De 1651, según el editor.

68 Ibíd., fol. $154 \mathrm{v} .^{\circ}$ De 1652 , según Martínez Grimaldo, que advierte que la poesía se hallaba en un papel escrito por nuestro autor. 


\section{f Ndice de primeros versos de QuiÑones a Benavente.}

¡Ah, Señor, el de lo branco! / Perdonad mi luenga costa. (Martinez Grimaldo, 1650.) Albricias, que llueve al justo / del cielo un dulce mará. (Id., 1657.)

Contaba una labradora / al cura de Zalamea. (Martínez Grimaldo, 1650.)

De aquel círculo de nieve / al cándido resplandor. (fd., 1657.)

De la piedra Jesús, piedra preciosa / y piedra de virtud y fortaleza. (Justa, 1609.)

En esta Ochava del Corpos / del señor San Sacramento. (Martínez Grimaldo, 1650.)

Hoy diz que sale de casa / el señor San Sacramento. (Id., 1657.)

Hoy un firme enamorado / mesa franca hace en el cielo. (Ibid.)

Juan Rana, insigne doctor, / altercando cierto punto (Cert., 1637.)

Oye, señor embozado, / ¿ para qué es ese disfraz? (Martinez Grimaldo, 1657.)

Pardiez, hermana Marica, / no sé qué diablos me tengo. (Ms. 3.773, BNM.)

Pelícano amoroso / que con el pecho abierto. (Martínez Grimaldo, 1657.)

Perdióse infiel a lo hermoso / por una fea mujer. (Cert., 1638.)

Señor don Diego Contreras, / mi amigo, ques más que deudo. (Ms. 3.799, BNM.)

Señor vestido de branco, / como en mi vida estorié. (Martinez Grimaldo, 1657.)

Voto al sol que estó atordido, / o créiganme o no me creigan. (Ibíd.) 